\title{
PCR-RFLP Analysis of D-Loop mtDNA in Indonesian Domestic Waterfowl
}

\author{
${ }^{\square}$. Susanti ${ }^{1}$, Fidia Fibriana ${ }^{2}$, Ari Yuniastuti ${ }^{1}$ \\ DOI: 10.15294/biosaintifika.v9i3.12177 \\ ${ }^{1}$ Department of Biology, Faculty of Mathematics and Natural Sciences, \\ Universitas Negeri Semarang, Indonesia \\ ${ }^{2}$ Department of Integrated Science, Faculty of Mathematics and Natural Sciences, \\ Universitas Negeri Semarang, Indonesia
}

\section{History Article}

Received 29 September 2017 Approved 26 November 2017 Published 31 December 2017

\section{Keywords}

Indonesian domestic waterfowl; mtDNA D-loop; PCRRFLP

\begin{abstract}
Phylogenetic or population genetic studies have been focused on finding genetic variations in mitochondrial DNA (mtDNA) because mutations in this region contained five times higher than other genetic materials. The aim of this research was to generate PCR-RFLP D-loop mtDNA profiles of some Indonesian domestic waterfowl. The samples were 35 local ducks, 5 muscovy duck, and 5 geese. These local ducks included on seven types of Javanese ducks in Central Java, i.e. Magelang duck, Peking duck, Pengging duck, Tegal Branjangan duck, Tegal Jarakan duck, Tegal Blorong duck, and Tegal Lemahan duck. PCR technique was used to amplify the D-loop genes, and RFLP analysis of the D-loop was performed with AluI and $R s a I$. The results show that muscovy duck has no restriction sites in D-loop gene. Moreover, goose has a restriction site of $A l u \mathrm{I}$ in D-loop gene at $550 \mathrm{bp}$ and 187 $\mathrm{bp}$; and it has no restriction site of RsaI. The analysis of RsaI-RFLP in mtDNA $D$-loop region of ducks resulted in 1 restriction fragment pattern which can be applied in the identification of duck to differentiate it from goose and muscovy duck. PCR-RFLP analysis duck D-loop mtDNA using AluI and RsaI restriction enzyme resulted in 3 combinations of restriction fragment pattern shown in 3 haplotypes (A, B, and C). Genetic diversity of Indonesian domestic waterfowl population could be identified by using PCR-RFLP analysis on mtDNA D-loop region. So far, there are few results of research on Indonesian domestic waterfowl genetic characteristics based on PCR-RFLP mtDNA D-loop marker. Also, this research has a good contribution on genetic characterization of local duck. The characterization is an important aspect to maintain breed quality and manage the genetic resources of Indonesian germplasm and in facilitating the breeding program.
\end{abstract}

\section{How to Cite}

Susanti, R., Fibriana, F., \& Yuniastuti, A. (2017). PCR-RFLP Analysis of D-Loop mtDNA in Indonesian Domestic Waterfowl. Biosaintifika: Journal of Biology \& Biology Education, 9(3), 537-544.

(C) 2017 Universitas Negeri Semarang 


\section{INTRODUCTION}

Waterfowl is a group of poultry which requires aquatic habitat. The characteristics of waterfowl are its genetic superiority, which is shown by its healthy level of body resistance compared to land birds. The cases of waterfowl deaths from infectious agents are rarely reported. The results revealed that waterfowls of the Anseriformes (especially duckling and goose) and Charadriiformes (especially seagull and pigeon) are the natural reservoirs of influenza viruses in Eurasia (Webster, Krauss, Hulse-Post, \& Sturm-Ramirez, 2007) Potential waterfowl as a reservoir VAI H5N1 (and ND virus) appears to be closely related to the natural limitation of this waterfowl immune system to eliminate virus (Feare \& Yasué, 2006). Nonetheless, as a species living in the aquatic environment, waterfowls have a mechanism to control the adverse effects of pathogens from the environment (Møller \& Erritzøe, 1998).

Waterfowl, as the source of egg and meat, is getting the attention of researchers. Meanwhile, duck meat and egg have proved a significant alternate of protein to the Indonesian people. Duck meat and egg have the typical nutrient content and taste at affordable prices (Matitaputty, 2012). The genetic conservation of domestic waterfowl is necessary. The Indonesian government's policy on mass culling or depopulation of chickens and other poultry within a radius of $1 \mathrm{~km}$ with the occurrence of $\mathrm{AI}$ subtype $\mathrm{H} 5 \mathrm{~N} 1$ virus infection has the potential to destroy germplasm wealth, such as the richness of waterfowl. Waterfowl conservation requires information on the genetic character. Conservation genetics or the application of genetics has received attention in recent years (Allendorf \& Luikart, 2009; Frankham, 2003). In conservation genetics, it is well known that genetic variation is the knowledge of the relatedness between individuals (Frankham, Briscoe, \& Ballou, 2002). Genetic characterization is necessary for efficient management of genetic resources (Bjørnstad \& Røed, 2002). One of the main objectives of conservation programs is the management of genetic diversity (Toro, Barragan, \& Ovilo, 2003). In the context of species conservation, genetic characterization is an important aspect of maintaining the integrity of a species as well as the management of genetic resources (Glowatzki-Mullis et al., 2006). Genetic characters can be assessed based on morphological characters, protein profiles, and molecular traits.

Molecular methods play a major role in estimating the genetic diversity among individuals by comparing the genotypes at some polymor- phic loci (Avise, 2012). Mitochondrial DNA (mtDNA) and nuclear DNA markers are included in several markers that are available for optimal applications (Sunnucks, 2000). The identification includes (i) its stability, allowing species identification even in heated and processed products; (Ii) the conserved nature of DNA structure in all tissues of an individual (Saini et al., 2007). Molecular analysis is a high-reliability approach, combined with quantitative approaches and traditional breeding strategies for design efficiency of preservation strategy (Dovc, Kavar, Sölkner, \& Achmann, 2006). The molecular marker cannot be affected by the environment and is stable (Moura et al., 2014). Several studies have shown that the use of two or more mtDNA markers will be stronger and stronger for genetic diversity analysis (Pedrosa et al., 2005).

RFLP-marker is a marker for the identification of organisms based on the analysis of DNA cut patterns. RFLP can be applied in biodiversity and phylogenetic studies of individuals in populations and species. PCR-RFLP technique difference exists in DNA fragment inter-individual within one family or population (Brown, 2016), which enables to develop as the alternative method to Analyze genetic diversity and individual genetic uniformity and diversity in native duck population. PCR-RFLP analysis has been applied to different species like tuna, lobster, and swine (Wolf, Rentsch, \& Hübner, 1999). It has served as a verification tool for food products from various animals (Rojas et al., 2011), and it is also used to identify meat characteristic on peacock (Pavo cristatus). A research using PCRRFLP analysis was also employed to reveal the molecular identity of plant accessions (Fibriana \& Hadiyanti, 2016).

In this study, PCR-RFLP analysis of mtDNA D-loop genes from domestic waterfowl (ducks, muscovy ducks, and geese) was performed to provide genetic data on effective conservation programs. Phylogenetic studies or genetic populations are more focused on finding the genetic variation of mitochondrial DNA (mtDNA) because mutations in this region are five times higher than other genetic material (Mannen et al., 2004; Pfeiffer, Voelkel, \& Brenig, 2005). Mitochondrial DNA contains a noncoding region termed the control region (CR or D-loop) due to its role in replication and transcription of $\mathrm{mtD}$ NA (Arif \& Khan, 2009). The D-loop segment exhibits a comparatively higher level of variation than protein-coding sequences due to reduced functional constraints and relaxed selection pressure. The non-coding region of mtDNA lies 
between the tRNA-Phe and tRNA-Pro genes. Dloop is a superlative marker which has the length approximately $1 \mathrm{~kb}$, and it was amplified by PCR easily before sequencing to determine the molecular diversity. D-loop has 2.8 to 5 times of other sections of mt-DNA (Xu, Wu, \& Yu, 2010). By using this gene, the sequence analysis of the $\mathrm{CR}$ of the sun bear is effective to measure the molecular diversity and to identify conservation units for the better manageability of this species (Onuma, Suzuki, \& Ohtaishi, 2006). The aim of this research was to generate PCR-RFLP D-loop mtDNA profiles of some Indonesian domestic waterfowl. The genetic diversity of Indonesian domestic waterfowl population could be identified by using PCR-RFLP analysis on mtDNA $D$-loop region. Only few research on Indonesian domestic waterfowl genetic characteristics based on PCR-RFLP mtDNA D-loop marker could be identified. In addition, this research will give a benefit in contribution on genetic characterization of Indonesian local duck. In fact, the characterization is an important aspect to maintain breed quality and manage the genetic resources of Indonesian germplasm and in facilitating the breeding program of waterfowl.

\section{METHODS}

Samples in this research were 35 local ducks, 5 muscovy duck, and 5 geese. Those local ducks consisted of seven types of Javanese ducks in Central Java, i.e. Magelang duck (IM1-5), Peking duck (IK1-5), Pengging duck (IG1-5), Tegal Branjangan duck (ITB1-5), Tegal Jarakan duck (ITJ1-5), Tegal Blorong duck (ITL1-5), and Tegal Lemahan duck (ITP1-5). Samples of domestic waterfowl with follicle were taken from the right and left wings. Feather samples used at the time of isolation only in the calamus and the rachis about $4-5 \mathrm{~cm}$ which is filled with marrow and had many networks. DNA isolation used gSYNC тм DNA Extraction Kit.

D-loop gene amplification was performed using KAPA 2G HotStart Ready Mix Kit with the composition of the $12.5 \mu \mathrm{L}$ ready mix; 1.5 $\mu \mathrm{L}$ of forward primer; $1.5 \mu \mathrm{L}$ of reverse primer, $7.5 \mu \mathrm{L}$ of ddH2O, and $2.0 \mu \mathrm{L}$ of DNA samples. Primers used were forward primer DL-AnasPF (L56) 5'-GTTGCGGGGTTATTTGGTTA-3 'and reverse primer DL-AnasPR (H773) 5'-CCATATACGCCAACCGTCTC-3' (Purwantini, Yuwanta, \& Hartatik, 2013). The PCR program was pre-denaturation $94^{\circ} \mathrm{C}$ for 5 minutes, denaturation $94^{\circ} \mathrm{C}$ for 30 seconds, annealing $56.1^{\circ} \mathrm{C}$ for 45 seconds, extension $72^{\circ} \mathrm{C}$ for $1 \mathrm{~min}$, and a final extension $72{ }^{\circ} \mathrm{C}$ for 5 minutes. The cycle is repeated 35 times. The $1.2 \%$ agarose gel was used to visualize the expected $718 \mathrm{bp}$ PCR product. Moreover, then, PCR product was separated by electrophoresis in $1.5 \%$ low-melting agarose gel using buffer $0.5 \times$ TBE. The RFLP analysis administered PCR products digested with endonuclease restriction enzyme $A l u \mathrm{I}$ and RsaI.

In a PCR tube $1 \mu \mathrm{L}$ endonuclease restriction enzyme added with $2 \mu \mathrm{L}$ buffer $\mathrm{R}$ and $7 \mu \mathrm{L}$ $\mathrm{dH} 2 \mathrm{O}$ free nuclease. After that, $5 \mu \mathrm{L}$ PCR product was added. The solution was then incubated at $37^{\circ} \mathrm{C}$ overnight for 16 hours. The PCR-RFLP was analyzed in $2 \%$ agarose gel electrophoresis. DNA band in agar gel was taken using the digital camera, and then it was tabulated then analyzed for the genetic diversity. The DNA band obtained from the visualization on each sample was then used to determine the haplotype, genetic uniformity, and diversity of waterfowl. Haplotype diversity obtained showed genetic diversity in waterfowl and the other native ducks.

\section{RESULTS AND DISCUSSION}

The DNA molecules have been the target compounds for species identification due to their high stability compared with proteins. DNA based-methods consist of the highly-specific amplification of one or more DNA fragments using PCR-restriction fragment length polymorphism (RFLP). The PCR-RFLP method is a simple, rapid, and cost-effective method for differentiation between species that is applicable in clinical laboratories (Mirhendi, Makimura, Khoramizadeh, \& Yamaguchi, 2006). The method has been used for the identification of five groups of fish (Hold et al., 2001), and it has been tested in 12 European laboratories. The method is reported to have a $96 \%$ success rate in the identification of samples of unknown origin. Previous researchers identified 16 species of gadoid fish by PCR and DNA sequencing (Calo-Mata et al., 2003). PCR-RFLP has also been described as the useful technique for the differentiation between Salmon species (Russell et al., 2000), Flatfish (Sotelo et al., 2001), Sturgeon-caviar (Ludwig, Debus, \& Jenneckens, 2002) and 23 Bony Fish over a wide range of species (Wolf, Burgener, Hübner, \& Lüthy, 2000).

The results showed that all samples were successfully extracted their DNA and amplified its D-loop genes. Genomic DNA obtained from isolation with gSYNC тM DNA Extraction Kit was $\pm 100 \mu 1$ per sample. A report shows that the quality of DNA obtained using commercial kits is better than using the K-SDS proteinase and al- 
kali method (Leekaew, Songserm, Choothesa, \& Boonyaprakob, 2008).

The D-loop genes of all samples in this study were successfully amplified using primers DL-AnasPF (L56) and DL-AnasPR (H773), with a product of $718 \mathrm{bp}$ (Figure 1). It suggests that the D-loop gene can be well amplified using primers DL-AnasPF and DL-AnasPR at an annealing temperature of $56.1^{\circ} \mathrm{C}$. Clear and thick bands indicate optimal PCR conditions so that the PCR process can proceed well. There is no single optimal PCR protocol for all genomes. Each PCR requires special optimization, especially template optimization and the primer to be used (Grunenwald, 2003).

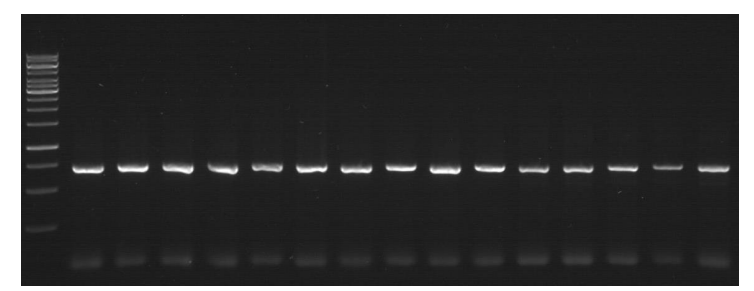

Figure 1. The result of D-loop genes amplification using primers DL-AnasPF (L56) and DLAnasPR (H773) showing a product of $718 \mathrm{bp}$

The success of amplification is determined by the primary suitability as well as the efficiency and optimization of the PCR process. Non-specific primers cause no amplified target genomic region or an amplified non-target genomic area. Annealing temperature optimization becomes the most important part of the amplification process (Roux, 2009). The annealing temperature is too low and too high to cause the primer cannot be attached to a specific place so that the target DNA amplification is not obtained. In this research, annealing temperature optimization is carried out using a temperature gradient at temperatures of $54.5^{\circ} \mathrm{C}, 55.0{ }^{\circ} \mathrm{C}, 55.5^{\circ} \mathrm{C}, 56.1^{\circ} \mathrm{C}, 56.9$ ${ }^{\circ} \mathrm{C}$ and $57.6^{\circ} \mathrm{C}$.

This study used two types of restriction enzymes that cut off the D-loop genes, namely $R s a \mathrm{I}$ and $A l u \mathrm{I}$. The RsaI enzyme intersects the Dloop gene into two fragments in all samples of $360 \mathrm{bp}$ and $390 \mathrm{bp}$ (Figure 2), except for muscovy ducks and swans. In other words, the D-loop muscovy ducks and goose genes in this study did not have a cutting site for RsaI enzymes. Meanwhile, the RsaI enzyme in all types of ducks in this study produced $360 \mathrm{bp}$ and $390 \mathrm{bp}$ fragments. Thus, RsaI-RFLP analysis on mtDNA D-loop of duck region yields 1 pattern of the restriction fragment. The ROMI D-loop restriction fragment pattern can be used for duck identification, and differentiate it from other waterfowl (i.e., swan and muscovy ducks).

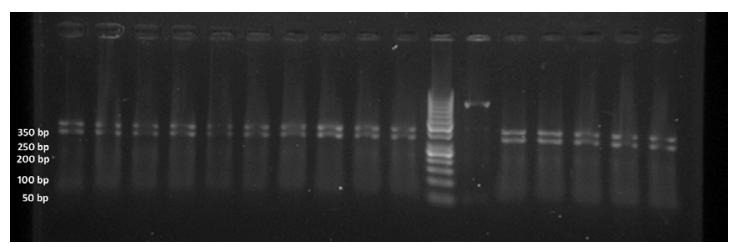

Figure 2. The RsaI enzyme intersects the D-loop gene into two fragments in all samples showing a product of $360 \mathrm{bp}$ and $390 \mathrm{bp}$

The $A l u$ I enzyme cuts the DNA into several variations of fragments for each, but not on muscovy ducks. The D-loop genes in this study did not have a cutting site for the AluI enzyme. In geese, the $A l u \mathrm{I}$ enzyme has a specific cutting site at $550 \mathrm{bp}$ and $187 \mathrm{bp}$. Thus, the RsaI-RFLP analysis of the mtDNA D-loop of the swan region produces a restriction fragment pattern, which distinguishes it from other waterfowl (ducks and muscovy ducks).

In ducks, $A l u \mathrm{I}$ enzyme cuts the genes resulted in 4 variations (i.e., 400, 350, 187 and 150bp) (Figure 3). AluI-RFLP analysis on $\mathrm{mtD}$ NA the D-loop of the duck region yields a pattern of 3 fragment restriction patterns. The pattern I with 350, and 187bp fragments in ITB1-5, IM1-5, and IG1-5 code ducks. Pattern II with fragment size 350,187 and 150bp in IK1-5 code ducks, ITL1-5, ITJ1-5, ITP1-2. Pattern III with fragment size $400,350,187$ and 150bp on ITP3-5 dot code. The three patterned pieces show genetic diversity in 7 species of ducks in Indonesia (Magelang duck, Peking duck, Pengging duck, Tegal Branjangan duck, Tegal Jarakan duck, Tegal Blorong duck, and Tegal Lemahan duck) based on the restriction fragment pattern of mtDNA D-loop region By AluI.

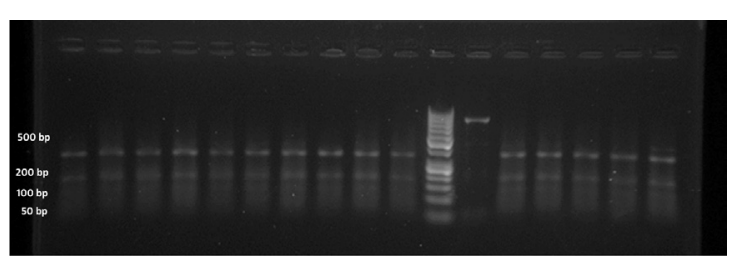

Figure 3. $A l u \mathrm{I}$ enzyme cuts the genes resulted in 4 variations (i.e., 400, 350, 187 and 150bp) in duck species

Analysis of PCR-RFLP in ducks with restriction enzymes $A l u \mathrm{I}$ and $R s a \mathrm{I}$ resulted in $3 \mathrm{com}$ binations of restriction patterns, thus forming 3 haplotypes (A, B and C). The haplotype fragment of mtDNA The D-loop region of the duck by the 
restriction enzyme AluI and RsaI is shown in Table 1 . The difference of restriction pattern shown in the study result with PCR-RFLP by using polymorphism sequence or nucleotide Sequence from mtDNA D-loop region fragment of domestic ducks.

Hao (2009) studied haplotype diversity (Hd) based on mtDNA D-loop region fragment in Cherry Valley duck in Taiwan. Cherry Valley is classified into two haplotype subgroups; the first homologies with Mallard duck (Anas zonorhyncha) and Jianchang duck, the second does not homologize or has the high variation with Mallard duck.

$\mathrm{Wu}$, Wan, and Fang (2006) have sequenced a portion of the mitochondrial control region (CR) (424 bp) to assess the population structure and gene flow among the populations of black muntjac (Muntiacus crinifrons) using 47 samples collected from three large populations. A total of 18 unique haplotypes ( 15 of them as populationspecific) were defined based on 22 polymorphic sites. It has been suggested that historical population expansion induced the coexistence of distinct haplotypes in a specific population after fragmentation and that the current genetic differentiation should be attributed to the reduction of femalemediated gene flow due to recent habitat fragmentation and subsequent loss (Wu et al., 2006). $\mathrm{Hu}$, Fang, and Wan (2006) have studied the genetic diversity and population structure of the Chinese water deer (Hydropotes inermis) by analyzing the $403 \mathrm{bp}$ fragment of mitochondrial D-loop. They have detected 18 different haplotypes in 40 samples demonstrating the haplotype diversity of 0.923 and nucleotide diversity of 1.318 , whereas no obvious phylogenetic structure among haplotypes was found for samples of different origin (Hu et al., 2006). Iyengar et al. (2006) have performed a comparative study of $\mathrm{CR}$ sequences from several captive oryx species and concluded a close grouping of Oryx leucoryx with Oryx gazelle instead of Oryx dammah. (Idaghdour, Broderick, Korrida, \& Chbel, 2004) have sequenced the 854 bp of the CR from the houbara bustard (Chlamy- dotis undulate) to describe the molecular diversity of this threatened cryptic desert bird, whose range extends from North Africa to Central Asia. F. Zhang and Jiang (2006) have used CR sequences to investigate the genetic diversity and evolutionary history of the Tibetan gazelle. A total of 25 CR haplotypes with high frequencies of both CR haplotype and nucleotide diversities were identified. These findings have suggested that the present population structure is the result of habitat fragmentation during the recent glacial period on the Qinghai-Tibet Plateau and it is likely that the present populations of Tibetan gazelle exhibit a pattern reminiscent of several bottlenecks and expansions in the recent past C. Zhang et al. (2010).

Some research reported that polymorphism analysis of mtDNA marker included ND1-6, ND4L, COX 1-3, ATP6 and ATP8 in Beijing duck in China (C. Zhang et al., 2010), prolactin gene polymorphism in purebred China duck (Shanma, Shaoxing, Youma, Jinyun, Jinjiang and interbred (F2) of white Liancheng and white Kaiya) (Wang et al., 2011) and polymorphism of growth hormone gene in Beijing duck, Xihu Mallards, Cherry Valley, Jinding duck, Shan Partridge duck, Jinjiang duck, Shaoxing duck and Partridge Jinyun (Hao, 2009) can be done by using PCRSSCP (Single Stranded Conformation Polymorphism) and the DNA sequencing products. The restriction profiles correspond to Wolf et al. (2000).

The combined analysis with more restriction enzymes is necessary for better results. (Moyer, Tiedje, Dobbs, \& Karl, 1996) reported that a combination of tetrameric restriction enzymes had good resolution on the phylogeny of their computer stimulated groups. Three or four endonuclease combinations are necessary for estimating approximate phylogenetic relationships among interspacer rDNA amplified from various environmental samples. In the present study, PCR-RFLP analysis using two restriction enzymes was demonstrated to the variation of domestic waterfowl. Thus, this PCR-RFLP method could serve as a rapid tool for estimating the ap-

Table 1. The mtDNA D-loop Region Fragment haplotype of domestic Ducks Based on Restriction Pattern of AluI and RsaI Enzyme

\begin{tabular}{lccc}
\hline $\begin{array}{l}\text { Haplotype } \\
\text { (Pattern AluI x Pattern RsaI) }\end{array}$ & $\begin{array}{c}\text { Restriction Site } \\
\text { AluI }\end{array}$ & $\begin{array}{c}\text { Restriction } \\
\text { Site RsaI }\end{array}$ & Duck species \\
\hline $\begin{array}{l}\text { Haplotype A } \\
\text { (Pattern I x Pattern I) }\end{array}$ & $350,187 \mathrm{bp}$ & $350,390 \mathrm{bp}$ & ITB1-5, IM1-5, IG1-5 \\
$\begin{array}{l}\text { Haplotype B } \\
\text { (Pattern II x Pattern I) }\end{array}$ & $350,187,150 \mathrm{bp}$ & $350,390 \mathrm{bp}$ & $\begin{array}{c}\text { IK1-IK 5, ITIL1- ITL } \\
5, \text { ITJ 1-5, ITP1-2 }\end{array}$ \\
$\begin{array}{l}\text { Haplotype C } \\
\text { (Pattern III x Pattern I) }\end{array}$ & $400,350,187$, & $350,390 \mathrm{bp}$ & $\begin{array}{c}\text { IG 1- IG 5,ITP } \\
\text { 3,ITP4,ITP5 }\end{array}$ \\
\hline
\end{tabular}


proximate phylogenetic relationship of isolates. This method is very simple and does not need other supporting procedures (Atalan, 2001).

In this study, the scientific name of waterfowl species has not been provided since the analysis of species name has not been conducted yet. Based on the research of Susanti et al. (2017), the Central Javanese duck is closely related to Anas platyrhynchos and Anas zonorynchos. Further analysis on the genetic relationship to obtain the scientific name is necessary. In this study, PCR-RFLP analysis of mtDNA D-loop genes from domestic waterfowl could provide genetic data on effective conservation programs of domestic waterfowls. The genetic data is important in facilitating breed quality and managing the genetic resources of Indonesian germplasm for the breeding program of local waterfowl.

\section{CONCLUSION}

The muscovy duck D-loop gene does not have a cutting site for $A l u \mathrm{I}$ or RsaI enzymes. Gen D-loop goose does not have a RsaI cutting site but has a cutting site with size $550 \mathrm{bp}$ and $187 \mathrm{bp}$. RsaI-RFLP analysis on mtDNA The d-loop of the duck region yields a restriction fragment pattern, which can then be used for duck identification, and distinguishes it from geese and muscovy ducks. PCR-RFLP analysis duck D-loop mtDNA using AluI and RsaI restriction enzyme resulted in 3 combinations of restriction fragment pattern shown in 3 haplotypes (A, B, and C). Genetic diversity of Indonesian domestic waterfowl population could be identified by PCR-RFLP analysis of mtDNA D-loop region. It is suggested that the combined analysis with more restriction enzymes is necessary to get more reliable results.

\section{ACKNOWLEDGEMENT}

The authors would like to express the sincere gratitude to the Ministry of Research, Technology and Higher Education of the Republic Indonesia, through Directorate Research Social Service (DRPM) for Fundamental Research Funding 2016.

\section{REFERENCES}

Allendorf, F. W., \& Luikart, G. (2009). Conservation and the genetics of populations. Hoboken: John Wiley $\&$ Sons.

Arif, I., \& Khan, H. (2009). Molecular markers for biodiversity analysis of wildlife animals: a brief review. Animal Biodiversity and Conservation, 32(1),
9-17.

Atalan, E. (2001). Restriction Fragment Length Polymorphism Analysis (RFLP) of Some Streptomyces Strains from Soil. Turkish Journal of Biology, 25(4), 397-404.

Avise, J. C. (2012). Molecular markers, natural history and evolution: Springer Science \& Business Media.

Bjørnstad, G., \& Røed, K. (2002). Evaluation of factors affecting individual assignment precision using microsatellite data from horse breeds and simulated breed crosses. Animal Genetics, 33(4), 264-270.

Brown, T. A. (2016). Gene cloning and DNA analysis: an introduction. Hoboken: John Wiley \& Sons.

Calo-Mata, P., Sotelo, C. G., Pérez-Martín, R. I., Rehbein, H., Hold, G. L., Russell, V. J., . . . Rosa, C. (2003). Identification of gadoid fish species using DNA-based techniques. European Food Research and Technology, 217(3), 259-264.

Dovc, P., Kavar, T., Sölkner, H., \& Achmann, R. (2006). Development of the Lipizzan horse breed. Reproduction in domestic animals, 41(4), 280-285.

Feare, C. J., \& Yasué, M. (2006). Asymptomatic infection with highly pathogenic avian influenza H5N1 in wild birds: how sound is the evidence? Virology Journal, 3(1), 96.

Fibriana, F., \& Hadiyanti, L. N. (2016). Phylogenetic Relationships of Local Durian Species based on Morphological Characteristics and PCRRFLP Analysis of the Ribosomal Internal Transcribed Spacer (ITS) DNA. Biosaintifika: Journal of Biology \& Biology Education, 8(3), 361369.

Frankham, R. (2003). Genetics and conservation biology. Comptes Rendus Biologies, 326, 22-29.

Frankham, R., Briscoe, D. A., \& Ballou, J. D. (2002). Introduction to conservation genetics: Cambridge University Press.

Glowatzki-Mullis, M., Muntwyler, J., Pfister, W., Marti, E., Rieder, S., Poncet, P., \& Gaillard, C. (2006). Genetic diversity among horse populations with a special focus on the FranchesMontagnes breed. Animal Genetics, 37(1), 33-39.

Grunenwald, H. (2003). Optimization of polymerase chain reactions. PCR protocols, 89-99.

Hao, Y. (2009). Genetic diversity analysis of mitochondrial D-loop region of Cherry Valley duck breed. Journal of Anhui Agricultural Science, 134, 279-282.

Hold, G. L., Russell, V. J., Pryde, S. E., Rehbein, H., Quinteiro, J., Vidal, R., ... Santos, A. T. (2001). Development of a DNA-based method aimed at identifying the fish species present in food products. Journal of agricultural and food chemistry, 49(3), 1175-1179.

Hu, J., Fang, S.-G., \& Wan, Q.-H. (2006). Genetic diversity of Chinese water deer (Hydropotes inermis inermis): implications for conservation. Biochemical genetics, 44(3-4), 156-167.

Idaghdour, Y., Broderick, D., Korrida, A., \& Chbel, F. (2004). Mitochondrial control region diversity 
of the houbara bustard Chlamydotis undulata complex and genetic structure along the Atlantic seaboard of North Africa. Molecular Ecology, 13(1), 43-54.

Iyengar, A., Diniz, F. M., Gilbert, T., Woodfine, T., Knowles, J., \& Maclean, N. (2006). Structure and evolution of the mitochondrial control region in oryx. Molecular phylogenetics and evolution, 40(1), 305-314.

Leekaew, P., Songserm, T., Choothesa, A., \& Boonyaprakob, U. (2008). A simple method to extract mitochondrial DNA in a non-invasive phylogenetic study of domestic native Thai ducks. Kasetsart Journal of Social Sciences, 42(42), 41-50.

Ludwig, A., Debus, L., \& Jenneckens, I. (2002). A molecular approach to control the international trade in black caviar. International Review of $\mathrm{Hy}$ drobiology, 87, 661-673.

Mannen, H., Kohno, M., Nagata, Y., Tsuji, S., Bradley, D., Yeo, J., . . Nomura, K. (2004). Independent mitochondrial origin and historical genetic differentiation in North Eastern Asian cattle. $\mathrm{Mo}$ lecular phylogenetics and evolution, 32(2), 539-544.

Matitaputty, P. R. (2012). Peningkatan produksi karkas dan kualitas daging itik melalui persilangan antara itik Cihateup dengan itik Alabio. Dissertations. Bogor Agricultural University.

Mirhendi, H., Makimura, K., Khoramizadeh, M., \& Yamaguchi, H. (2006). A one-enzyme PCRRFLP assay for identification of six medically important Candida species. Nippon Ishinkin Gakkai Zasshi, 47(3), 225-229.

Møller, A. P., \& Erritzøe, J. (1998). Host immune defence and migration in birds. Evolutionary Ecology, 12(8), 945-953.

Moura, A. E., Tsingarska, E., Dąbrowski, M. J., Czarnomska, S. D., Jędrzejewska, B., \& Pilot, M. (2014). Unregulated hunting and genetic recovery from a severe population decline: the cautionary case of Bulgarian wolves. Conservation Genetics, 15(2), 405-417.

Moyer, C. L., Tiedje, J. M., Dobbs, F. C., \& Karl, D. M. (1996). A computer-simulated restriction fragment length polymorphism analysis of bacterial small-subunit rRNA genes: efficacy of selected tetrameric restriction enzymes for studies of microbial diversity in nature. Applied and Environmental Microbiology, 62(7), 2501-2507.

Onuma, M., Suzuki, M., \& Ohtaishi, N. (2006). Possible conservation units of the sun bear (Helarctos malayanus) in Sarawak based on variation of mtDNA control region. Japanese Journal of Veterinary Research, 54(2-3), 135-139.

Pedrosa, S., Uzun, M., Arranz, J.-J., Gutiérrez-Gil, B., San Primitivo, F., \& Bayón, Y. (2005). Evidence of three maternal lineages in Near Eastern sheep supporting multiple domestication events. Proceedings of the Royal Society of London B: Biological Sciences, 272(1577), 2211-2217.

Pfeiffer, I., Voelkel, I., \& Brenig, B. (2005). Phylogenetics of the European Dahomey miniature cattle based on mitochondrial D-loop region DNA sequence. Animal Genetics, 36(2), 179-181.

Purwantini, D., Yuwanta, T., \& Hartatik, T. (2013). Polymorphism of D-loop mitochondrial DNA region and phylogenetic in five Indonesian native duck population. International Journal of Poultry Science, 12(1), 55.

Rojas, M., González, I., Pavón, M., Pegels, N., Hernández, P., García, T., \& Martín, R. (2011). Mitochondrial and nuclear markers for the authentication of partridge meat and the specific identification of red-legged partridge meat products by polymerase chain reaction. Poultry science, 90(1), 211-222.

Roux, K. H. (2009). Optimization and troubleshooting in PCR. Cold Spring Harbor Protocols, 2009(4), pdb. ip66.

Russell, V. J., Hold, G. L., Pryde, S. E., Rehbein, H., Quinteiro, J., Rey-Mendez, M., . . . Rosa, C. (2000). Use of restriction fragment length polymorphism to distinguish between salmon species. Journal of agricultural and food chemistry, 48(6), 2184-2188.

Saini, M., Das, D., Dhara, A., Swarup, D., Yadav, M., \& Gupta, P. (2007). Characterisation of peacock (Pavo cristatus) mitochondrial 12S rRNA sequence and its use in differentiation from closely related poultry species. British poultry science, 48(2), 162-166.

Sotelo, C. G., Calo-Mata, P., Chapela, M. J., PérezMartín, R. I., Rehbein, H., Hold, G. L., . . . Izquierdo, M. (2001). Identification of flatfish (Pleuronectiforme) species using DNA-based techniques. Journal of agricultural and food chemistry, 49(10), 4562-4569.

Sunnucks, P. (2000). Efficient genetic markers for population biology. Trends in ecology \& evolution, 15(5), 199-203.

Toro, M., Barragan, C., \& Ovilo, C. (2003). Estimation of genetic variability of the founder population in a conservation scheme using microsatellites. Animal Genetics, 34(3), 226-228.

Wang, C., Liang, Z., Yu, W., Feng, Y., Peng, X., Gong, Y., \& Li, S. (2011). Polymorphism of the prolactin gene and its association with egg production traits in native Chinese ducks. South African Journal of Animal Science, 41(1).

Webster, R. G., Krauss, S., Hulse-Post, D., \& SturmRamirez, K. (2007). Evolution of influenza A viruses in wild birds. Journal of wildlife diseases, 43(3_Supplement), S1.

Wolf, C., Burgener, M., Hübner, P., \& Lüthy, J. (2000). PCR-RFLP analysis of mitochondrial DNA: differentiation of fish species. LWT-Food Science and Technology, 33(2), 144-150.

Wolf, C., Rentsch, J., \& Hübner, P. (1999). PCR $\square$ RFLP analysis of mitochondrial DNA: A reliable method for species identification. Journal of agricultural and food chemistry, 47(4), 13501355.

Wu, H.-L., Wan, Q.-H., \& Fang, S.-G. (2006). Population structure and gene flow among wild 
R. Susanti, Fidia Fibriana, Ari Yuniastuti / Biosaintifika 9 (3) (2017) 537-544

populations of the black muntjac (Muntiacus crinifrons) based on mitochondrial DNA control region sequences. Zoological science, 23(4), 333-340.

Xu, X., Wu, X., \& Yu, Z. (2010). The mitogenome of Paphia euglypta (Bivalvia: Veneridae) and comparative mitogenomic analyses of three venerids. Genome, 53(12), 1041-1052.

Zhang, C., Wang, Y., Xie, M., Chen, M., Wang, X.,
\& Hou, S. (2010). Mitochondrial coding gene polymorphisms associated with carcass traits in Beijing duck. Journal of Animal and Veterinary Advances, 9(19), 2522-2525.

Zhang, F., \& Jiang, Z. (2006). Mitochondrial phylogeography and genetic diversity of Tibetan gazelle (Procapra picticaudata): implications for conservation. Molecular phylogenetics and evolution, 41(2), 313-321. 